\title{
TID/SNA-- 13
}

TEST FACILITY PERFORMANCE REQUIREMENTS

FOR ETS-1

NERVA Program, Contract SNP-1

September 1970

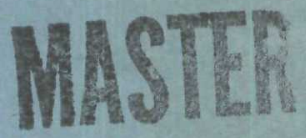

\footnotetext{
DISTRIBUTION OF THIS DOCUMENT UNLIMITED
} 


\section{DISCLAIMER}

This report was prepared as an account of work sponsored by an agency of the United States Government. Neither the United States Government nor any agency Thereof, nor any of their employees, makes any warranty, express or implied, or assumes any legal liability or responsibility for the accuracy, completeness, or usefulness of any information, apparatus, product, or process disclosed, or represents that its use would not infringe privately owned rights. Reference herein to any specific commercial product, process, or service by trade name, trademark, manufacturer, or otherwise does not necessarily constitute or imply its endorsement, recommendation, or favoring by the United States Government or any agency thereof. The views and opinions of authors expressed herein do not necessarily state or reflect those of the United States Government or any agency thereof. 


\section{DISCLAIMER}

Portions of this document may be illegible in electronic image products. Images are produced from the best available original document. 


\section{AEROJET}

GEMERALTIR

GENERAL

T134-TFR01-w113f7

\section{TEST FACILITY PERFORMANCE REQUIREMENTS FOR ETS-1}

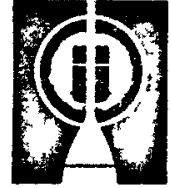

September 1970

This report was prepared as an account of work sponsored by the United States Government. Neither the United States nor the United States Energy Research and Development Administration, nor any of their employees, nor any of their contractors, subcontractors, or their employees, makes any warranty, express or implied, or assumes any legal liability or responsibility for the accuracy, completeness or usefulness of any information, apparatus, product or process disclosed, or represents that its use would not infringe privately owned rights.
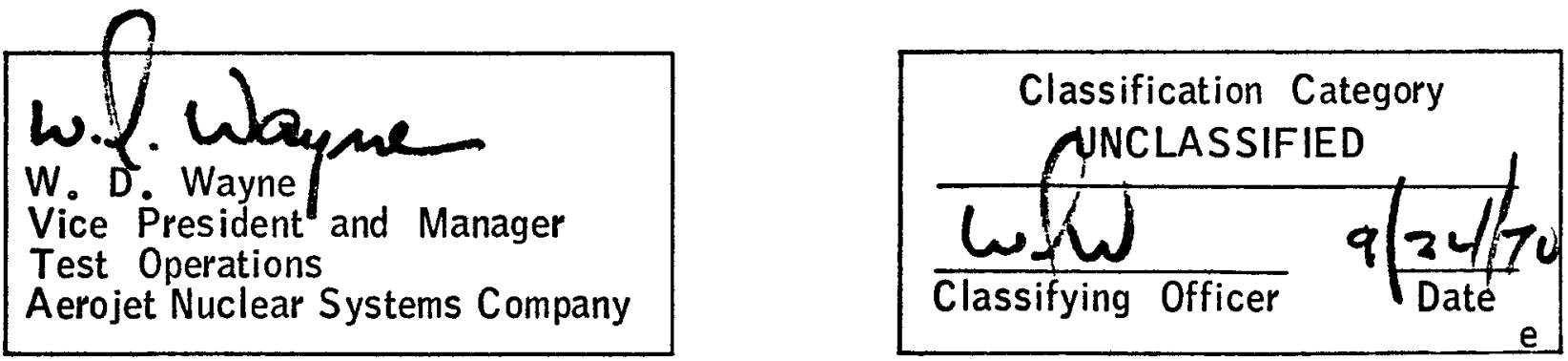
CONTENTS

Page

1.0 Scope

1

2.0 Test Article Description

1

2.1 Identification of Test Articles

2.2 Test Article' - ETS-1 Interfaces

3.0 Facility/Test Assembly Performance Requirements 3

3.1 Accumulation of Detailed Requirements 4

3.2 Unidentified Requirements 5

4.0 Summary of Facility/Test Assembly Performance Requirements 6

4.1 Mechanica1

4.2 Propellant

4.3 Pressurization Fluid

4.4 Cooldown Fluid

4.5 Emergency Cooldown Fluid

4.6 Purge Fluid

4.7 Exhaust Fluid

4.8 Measurement Requirements

4.9 Computation Requirements

4.10 Events Recording Requirements

4.11 Control Requirements 


\section{TABLES}

No.

$1 \quad$ Facility Requirements

2 Engine Measurement List Summary

3 Facility Computer Calculation Criteria Summary

4 Events Chronology

REFERENCE TABLES

(See Table 1)

No.

E-1 Measurement System Criteria

E-2 Computer Calculation Criteria

F-1 Propellant Fluid Requirements at Interface

F-2 Pressurization Fluid Requirements at Interface

F-3 Cooldown Fluid Requirements at Interface

F-4 Emergency Cooldown Fluid Requirements at Interface 


\section{$1.0 \quad \underline{\mathrm{SCOPE}}$}

The purpose of this document is to identify and delineate the performance requirements imposed upon the ETS-1 facility by the test article. Eventually, these requirements will be imposed by the NERVA Verification Plan, T-102, and in particular the associated Verification Information Sheets, VIS's. This document will be used to screen, interpret, and consolidate these requirements into a single source that combines all test-article-imposed facility performance requirements and the background information necessary for their implementation. Because of the T-102 VIS's are not yet written, this initial draft is based upon Section 3 of the NERVA Engine Specification (Data Item C002-CP090290-F1). Modifications and additions are anticipated in subsequent editions that will reflect the NERVA program's maturity as documented by formal data items.

\subsection{TEST ARTICLE DESCRIPTION}

The test article is a NERVA engine and the test-stand adapters necessary for incorporation of the engine into the ETS-1 test facility. A detailed description of the reference engine may be found in the NERVA Engine Reference Data Book (Data Item S-130). Figure I of Data Item E-106 will, show the enginefacility interface envelope and the engine's performance, design, and qualification requirements as presented in Data Item C002-CP090290-F1.

In general, each of the test articles is assembled in E-MAD and transported by rail to ETS-1, then installed within the engine test compartment (ETC). The test article also includes those system components or items of hardware directly related to, or required for, the performance of the engine. 


\subsection{IDENTIFICATION OF TEST ARTICLES}

The test articles currently assigned to ETS-1, the expected date of installation, and references to their general description are as follows:

Test Artic1
E-1(DE-1)
E-2(PQE-1)
E-3(PQE-2)
E-5(QE-1)
E-8(QE-3)

Scheduled Installation Date* Description Reference November 1974 4.1 .1

July 1977 4.1 .2

December 1977 4.1 .2

December 1979

4.1 .3

February 1980

4.1 .3

\subsection{TEST ARTICLE - ETS-1 INTERFACES}

Data Item E-106 (Engineering Data for Interface Control) provides definition of interfaces between the test article and the test facility. This data item will define the interface requirements and also interface designs that comply with the requirements. The interfaces will be categorized as engine-facility hardware interfaces. * The following interface parameters will be defined for each hardware interface (e.g., TSA-to-Facility):

Dimensional, including envelope

F1uid

Electrical

Structural

*These installation dates are arbitrarily six weeks ahead of the power tests dates obtained from $\mathrm{PD}-1255 \mathrm{~B}$. 
In addition, Data Item E-106 will delineate the interface hardware responsibilities and, for engine ground tests, will consist of one interface control drawing (ICD) for each engine ground test article. (ICD-1137421 has been assigned for the DE-1 test article).

The interface between the test article and the facility will be universal; consequently, an adapter section (TSA) will be required for mating to specific engine configurations. The adapter section will be designed to simulate the stage-engine interface and will be considered as test article hardware. Capability for remote installation or removal of the adapter will not be required.

Ground test support required $l_{y}$ LEATis diglcal inscrumencation añd control electronics (NDICE) will be supplied by the ground test control system (GTCS). A11 facility-to-NDICE functional interactions will be through the GTCS system. The GTCS will include the following:

1. Control room consoles

2. Digital test command system

3. NDICE support

4. Engine-reactor safety system

5. Ground-test simulation system

6. Verification test equipment

\subsection{FACILITY-TEST ASSEMBLY PERFORMANCE REQUIREMENTS}

Verification of certain NERVA engine performance characteristics by testing at ETS-1 imposes requirements and restrictions upon the facility. Identification of the accompanying hardware modifications and operating procedures is the first step necessary for subsequent implementation of these modifications and procedures. The performance requirements of the engine and its testing philosophy, are specifically identified in the NERVA Engine Specification: 
This testing philosophy, as delineated and enlarged upon in the NERVA Test Program Plan (Data Item T-101), in conjunction with NERVA performance requirements as presented in the engine specification, permits the identification of a specific testing methodology that is collected and presented in the NERVA Verification Plan (Data Item T-102). Data Item T-102 is: (1) the vehicle for the collection of verification information sheets in which individual test requirements are identified and described; and (2) the means for verification of individual performance requirements. These verification test requirements, in turn, impose performance requirements upon the test facilities. It is the purpose of this document, to translate these test-article-oriented test requirements into facility-oriented performance requirements.

In particular, this document will identify those functional requirements imposed upon ETS-1 by the NPRD (as specifically delineated in Section 3 of the engine specification) in such a way that the technical information necessary for the planning, management, and design of ETS-1 modifications will be readily available.

\subsection{ACCUMULATION OF DETAILED REQUIREMENTS}

Table 1 is a master requirements table which is an accumulation of the interface requirements and any additional uncategorized requirements that result from the specific performance specified in Section 3 of the engine specification. These requirements have been developed with specific reference to each subsection of the engine specification on a subsection-by-subsection basis and the subsection number has been retained in Table 1 as a reference. Note that the table entries are the specific requirements placed upon the facility by the engine as interpreted from the specification. No attempt has been made in Table 1 to amalgamate the requirements or relate them to other similar requirements. This process necessarily creates some repetition but insures that all facility requirements imposed by the engine are treated. 
Supplementing this table are Reference Tables $E-1$ and -2 and $F-1,-2,-3$, and -4 which more specific and detalled information relative to the individual requirements is accumulated.

\subsection{UNIDENTIFIED REQUIREMENTS}

It is important to note that the facility requirements identified In these tables are known to be incomplete and in some cases inadequate as a basis for the modification of ETS-1. As described earlier, these requirements are derived directly from Section 3 of the engine specification: consequently, they represent judgements that will be altered as the program's system documentation continues to be created, verified, and refined. 


\subsection{SUMMARY OF FACILITY/TEST ASSEMBLY PERFORMANCE REQUIREMENTS}

The individual requirements imposed upon the facility by the performance and qualification requirements of the engine have been examined and compared to identify the controlling requirement in each category. These requirements are assembled herein to facilitate the identification of requirements for ETS-1 design and modification. Narrative statements of facility performance requirements are the most severe of their type. The summary requirements are intended to serve as the criteria for determining the necessity for modifying ETS-1 and, where necessary, to provide quantitative information for modification design.

\subsection{MECHANICAL}

The ETS-1 facility must support vertical, upward, steady-state thrust loads of up to $77,400 \mathrm{lb}$, including the specification 1 imit resulting from operation of the NERVA engine at full power. Attendant vibration loadings, as well as the vertical, downward, dead weight of the engine of $35,0001 \mathrm{~b}$ (with shield) or $25,000 \mathrm{lb}$ (without shield) must be accommodated. Operation will be steady but intermittent at full-and partial-thrust loads, and transient thrust loads between these values will be accommodated. The maximum rate of change of thrust will be that corresponding to a chamber pressure rate of change of $50 \mathrm{psi} / \mathrm{sec}$. Gimbaling of the engine will be accomplished while the engine is under test so the thrust loads may deviate from the vertical by $0.50^{\circ}$ in any direction.

\subsection{PROPELIANT}

Liquid hydrogen propellant will be supplied to the engine at varying flow rates to $94.8 \mathrm{lb} / \mathrm{sec}$. The facility will be capable of delivering $\cdots$ liquid hydrogen simultaneously to both propellant supply lines at a maximum flow rate of $76.4 \mathrm{lb} / \mathrm{sec}$. The liquid hydrogen will be delivered at a purity quality specified by MSFC 356 and at a temperature between 39.1 to $41.1^{\circ} \mathrm{R}$ and 
a pressure witnin the range of 12.8 to 30.0 psia. Maximum daily propellant utilization will be $341,680 \mathrm{Ib}$.

\subsection{PRESSURIZATION FLUID}

The facility will accept gaseous hydrogen run-tank pressurization fluid at flow rates to $1.51 \mathrm{lb} / \mathrm{sec}$. The gaseous hydrogen will be removed from the engine at a temperature between 243 and $336^{\circ} \mathrm{R}$ and at a pressure between 12.8 and 729 psia. The facility will be capable of using the hydrogen for runtank pressurization while the engine is operating as well as disposing of the hydrogen by flaring or other means. Maximum.daily pressurization-fluid utilization will be $1,8361 \mathrm{~b}$.

\subsection{COOLDOWN FLUID}

The facility will be capable of supplying liquid hydrogen to the cooldown line in pulses of varying duration and frequency for $24 \mathrm{hr}$ following pump tailoff. The maximum flow rate required is $1.7 \mathrm{lb} / \mathrm{sec}$. The fluid will be supplied at a pressure between 42.8 and $12.8 \mathrm{psia}$ and at a temperature between 39.1 and $45.0^{\circ} \mathrm{R}$. Daily maximum cooldown-fluid utilization will be $6,0001 b$.

\subsection{EMERGENCY COOLDOWN FLUID}

The facility will accept liquid hydrogen emergency cooldown fluid from the pump discharge lines at a maximum flow rate of $1 \mathrm{lb} / \mathrm{sec}$. Cooldown fluid temperature will be in the range 39.6 to $63.4^{\circ} \mathrm{R}$ and pressure will be in the range of 1328 to 1447 psia.

A facility requirement to deliver cooldown fluid to the engine in ..., the event of an emergency is not implied by the engine specification. The details of this requirement will be based upon VIS's when they become available. . 


\subsection{PURGE FLUID}

Gaseous hydrogen, gaseous nitrogen, and helium will be provided by, the facility as engine purge gases. The flow rates and temperature and pressure requirements will be determined.

\subsection{EXHAUST FLUID}

The facility will accept hot gaseous hydrogen from the engine at its nozzle exit plane at flow rates to $94.3 \mathrm{lb} / \mathrm{sec}$. The hydrogen will be delivered at conditions corresponding to chamber temperatures to $4317^{\circ} \mathrm{R}$ and chamber pressures to $458 \mathrm{psia}$. The back pressures must be such that a nozzle

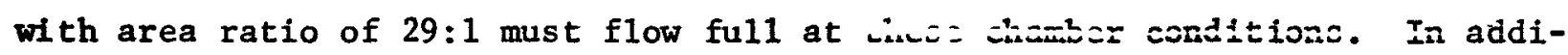
tion, the facility must provide the capability for simulating altitude during all powered portions of each run and during all cooldown operations.

Specification of a magnitude and duration requirement for back pressure is not possible at this time. It appears that the controlling engine performance criterion (with respect to back pressure) is choking at the nozzle throat during cooldown which requires a back pressure of 0.5 psia for up to several hours. It must be emphasized that this value is not now a requirement of the facility but it may become the formal requirement in order to verify analytical models and computational routines that predict the flight vehicle's total cooldown-fluid loading requirements.

A back-pressure requirement to permit verification of total impulse uncertainty of $\pm 20,0001 \mathrm{~b}-\mathrm{sec}$ does not exist. All values of back pressure upon which total-impulse-uncertainty analyses were based showed uncertainties ranging upward from approximately an order of magnitude greater than the $20,0001 \mathrm{~b}-\mathrm{sec}$ requirement. Verification of this impulse uncertainty requirement may prove to be a problem but it does not appear to be significantly related to back pressure. 
The maximum back pressure required to insure the structural integrity of the 29:1 nozzle shell has not yet been determined for all test conditions contemplated. Analyses completed, however, indicate that atmospheric pressure will restrict testing to chamber pressures of less than 227 psia in order to prevent excessive stress because of vibration loading. The corresponding flow rate into the proposed duct will itself reduce the back pressure significantly and permit operation at higher chamber pressures, but the limit associated with the more realistic configuration has not yet been determined.

Additional requirements that may be imposed upon the NASS facility by the engine are related to the performance of the gimbaling system and to the possible engine-duct misalignment. These requirements haye been identified, but quantitative information needed to relate them to facility requirements is not available at this time.

\subsection{MEASUPEMENT REQUIREMENTS}

Table 2 is a compilation of all engine measurement requirements that must be processed by the facility data system.

\subsection{COMPUTATION REQUIREMENTS}

Table 3 is a compilation of all calculated parameters that must be processed by the facility ADP system.

4.10 EVENT RECORDING REQUIREMENTS

Table 4 describes events chronology requirements. 


\section{I CON'ROL REQUIREMENT}

Normal control and sequencing of command signals during engine test operations will be provided by the NDICE system. The facility will

provide command signals to initiate startup. In addition, the facility will provide manual override control for all engine valves and actuators. 
TABLE. 1

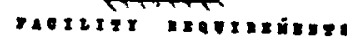

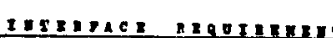

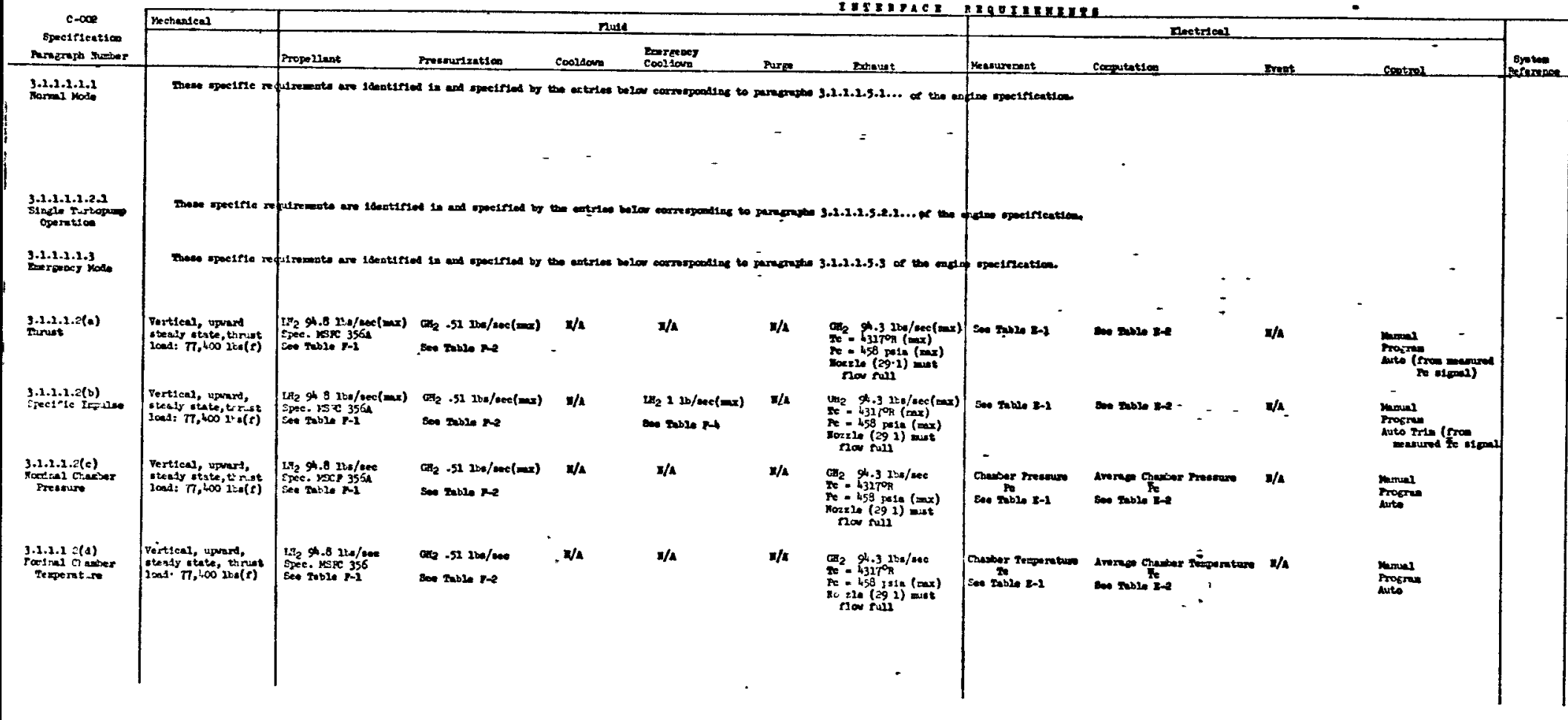

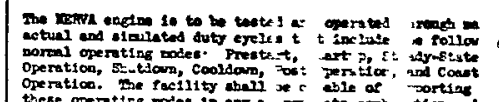

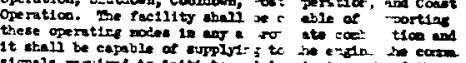

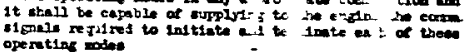

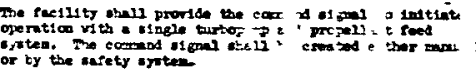

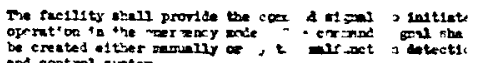

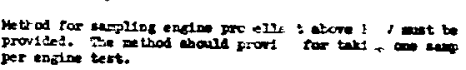

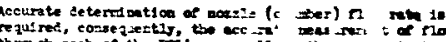

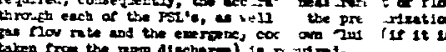

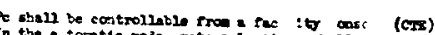

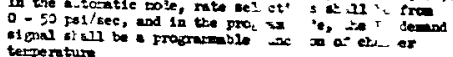

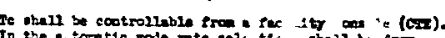

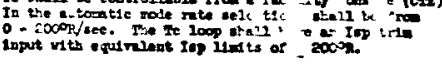


TABLE 1 (cont.)

2 or 9

pacteizy nequasunase

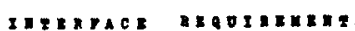

and

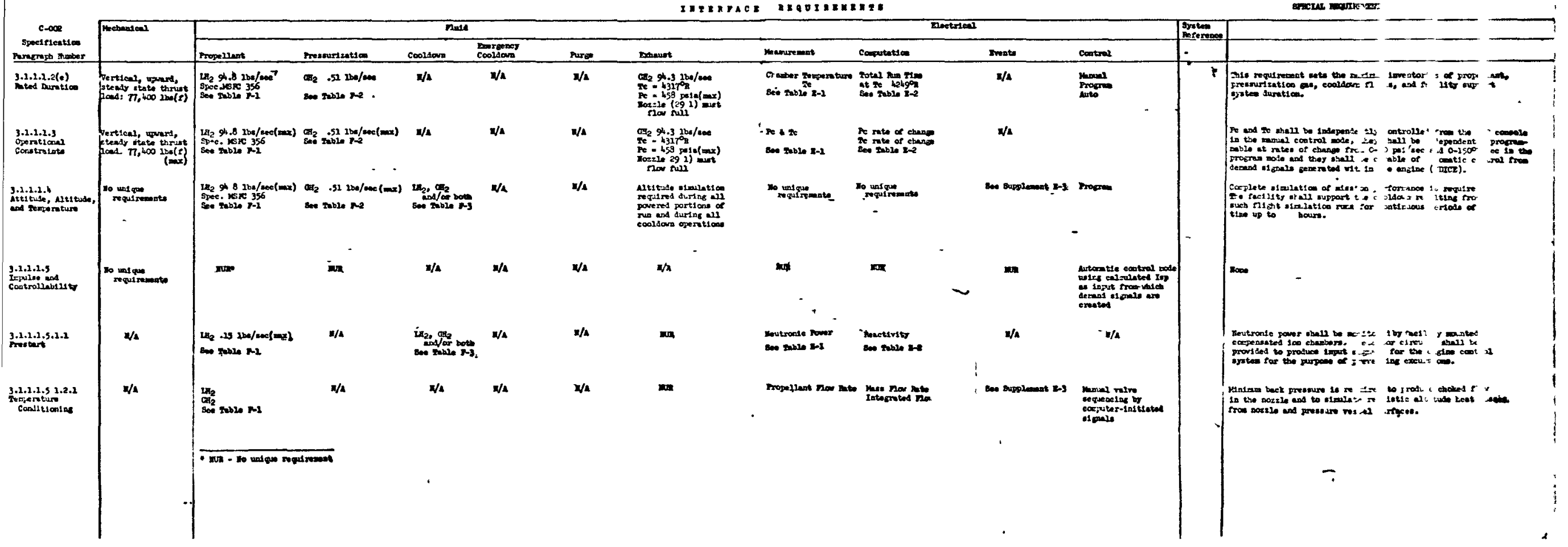




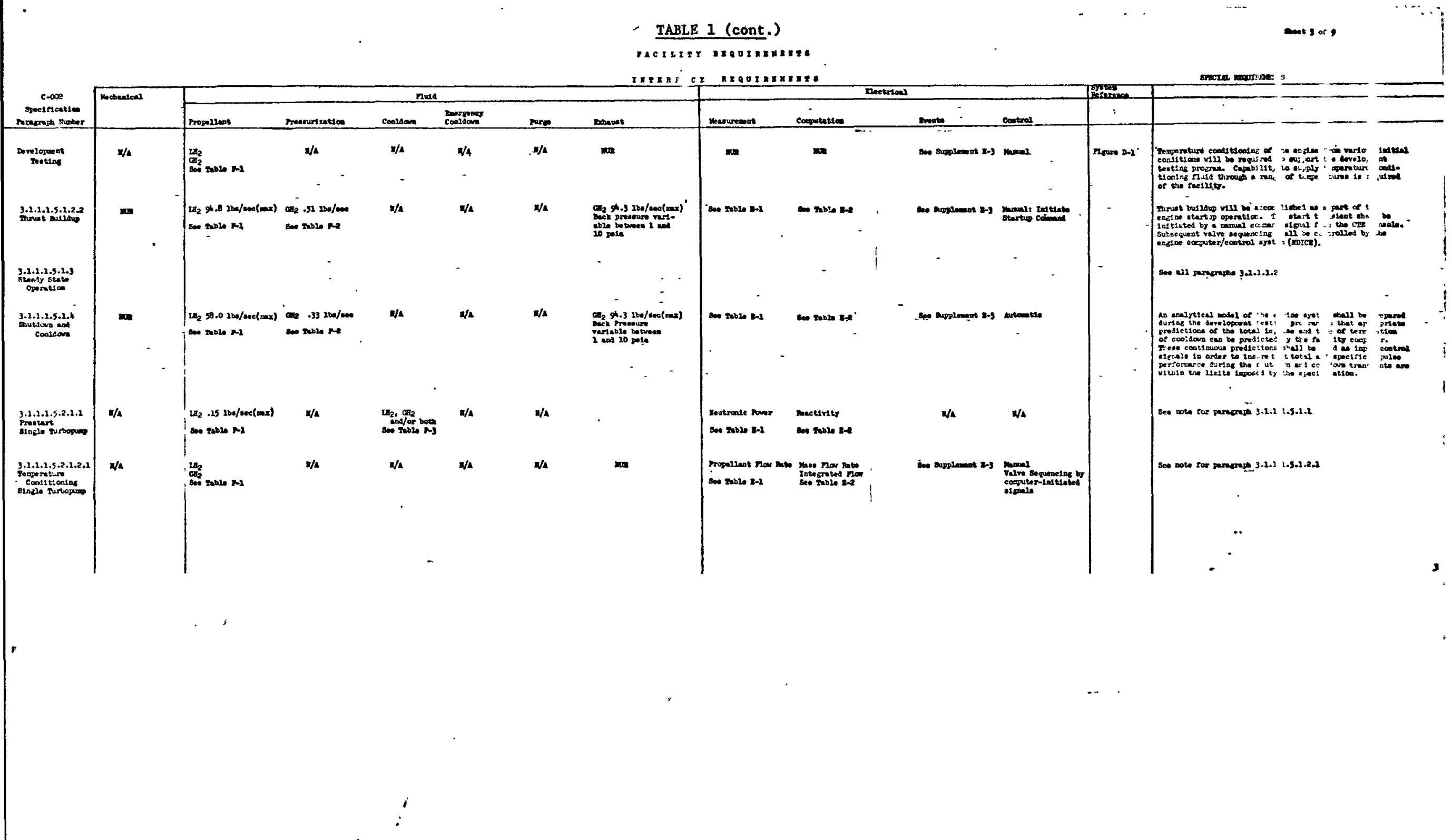


NA12198 210021143800

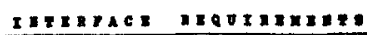

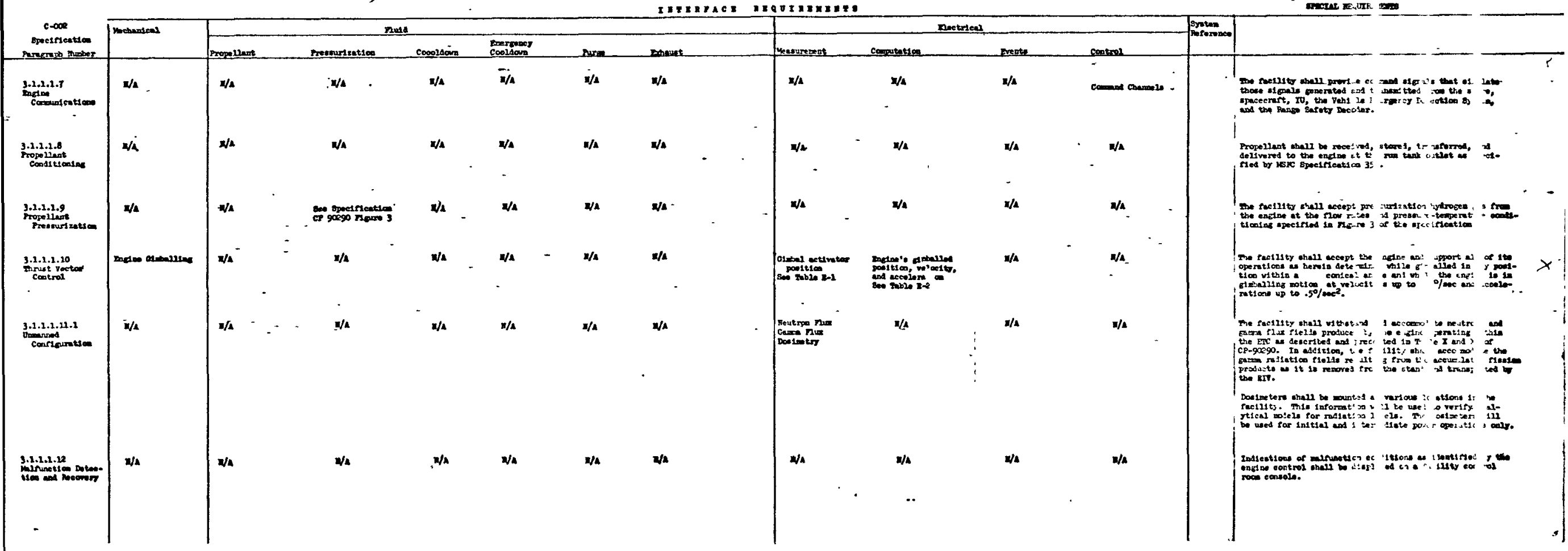


TABLE 1 (cont.)

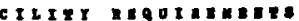

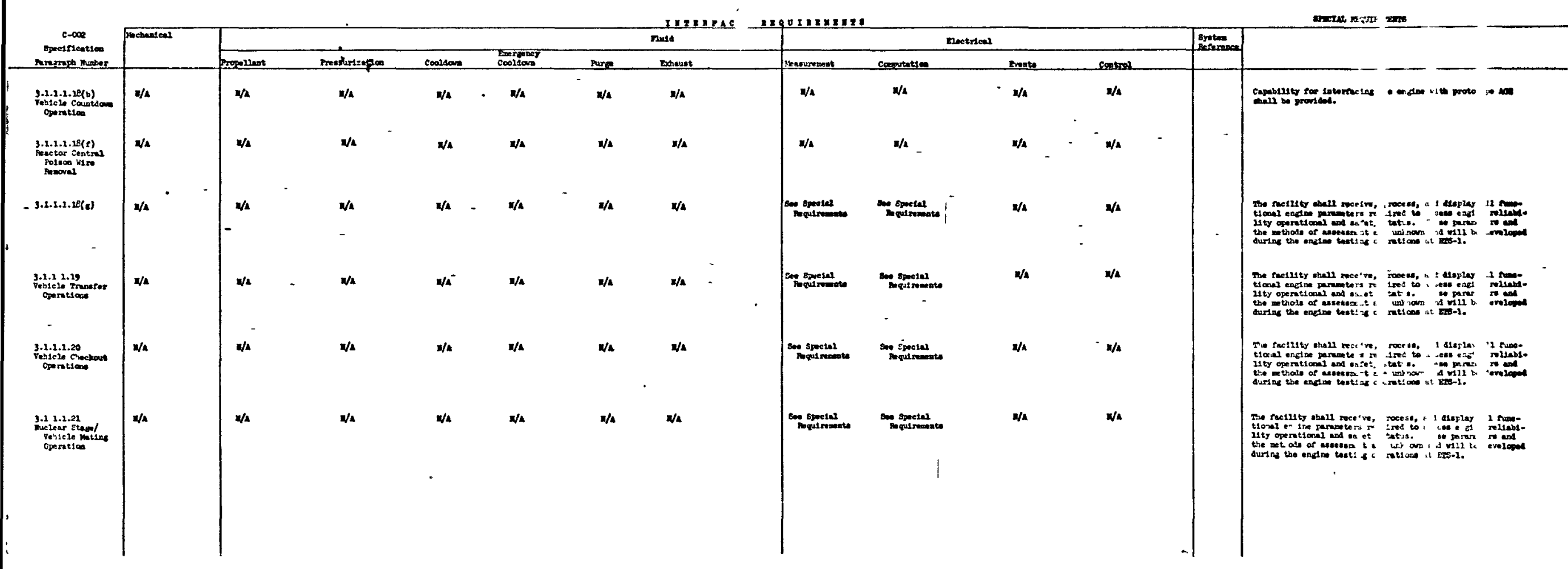


TABLE 1 (cont.)

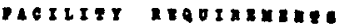

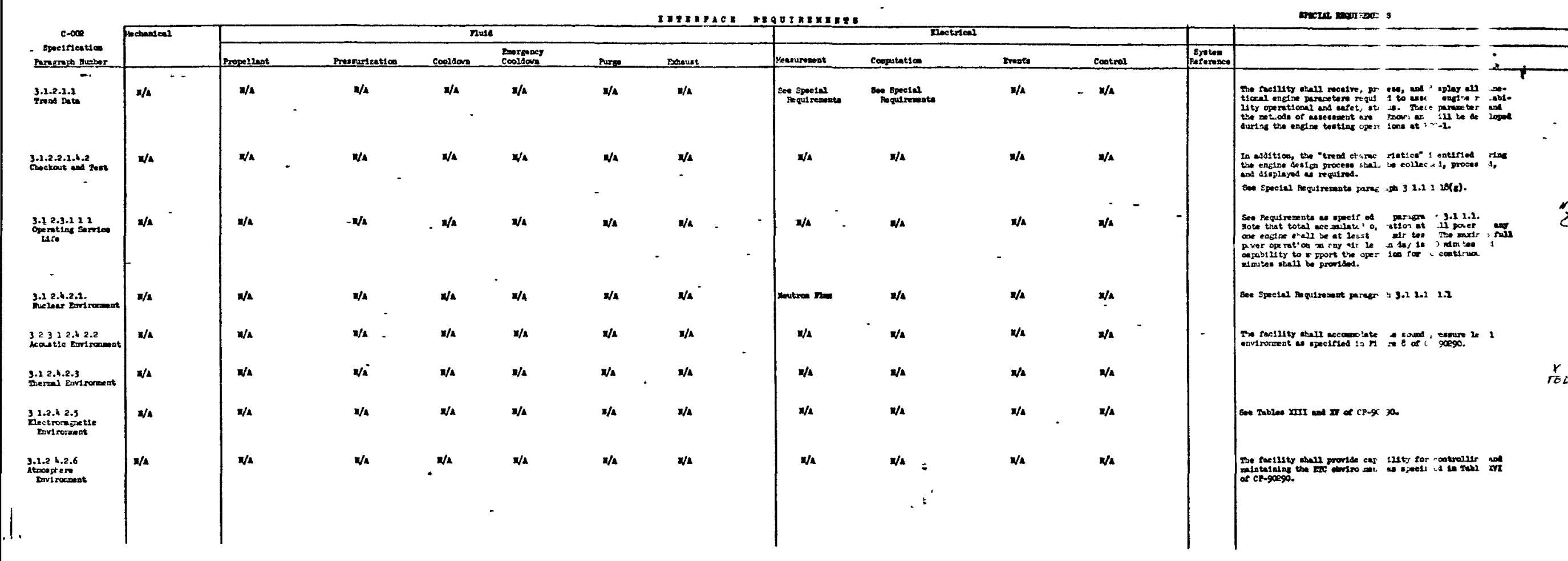


TABLE 1 (cont.)

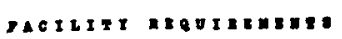

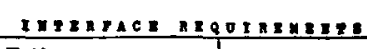

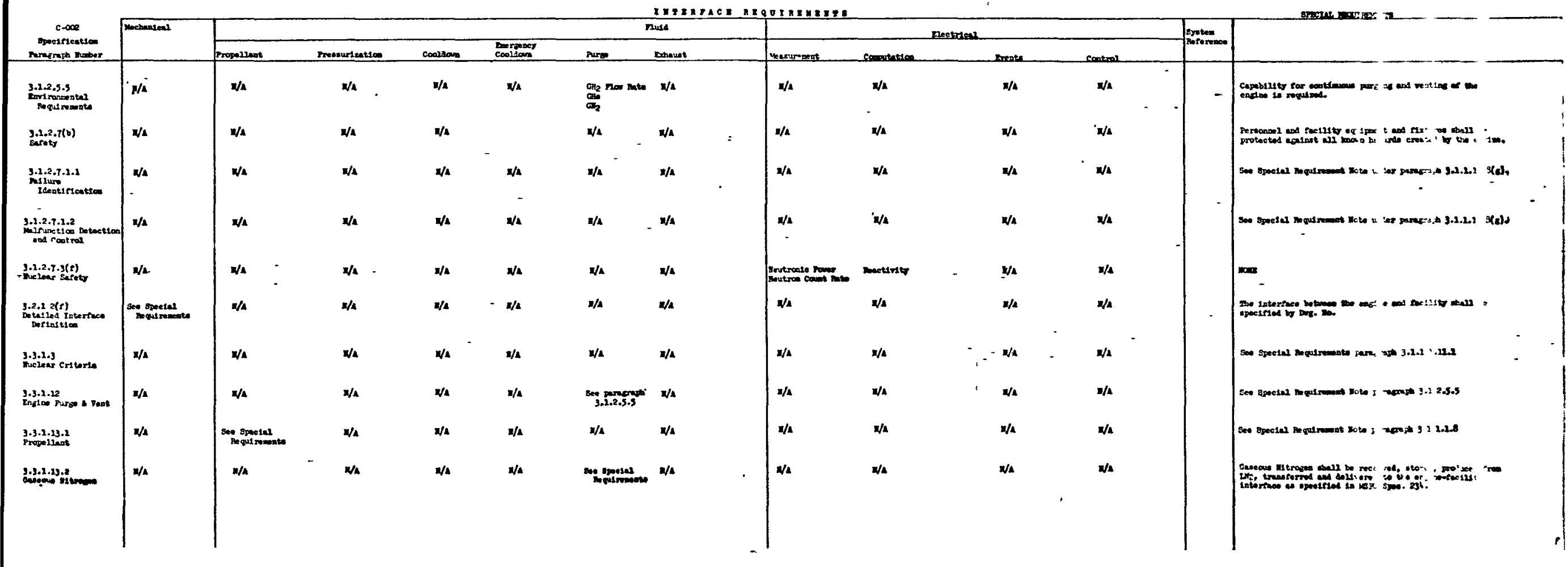




\section{TABLE 2}

ENGINE MEASUREMENT LIST SUMMARY

Parameter

Chamber Pressure

Chamber Temperature

Propellant Volumetric Flow Rate

Propellant Pressure

Propellant Temperature

Pressurization Fluid Volumetric Flow Rate

Pressurization Fluid Pressure

Pressurlzation Fluid Temperature

Bmergency Coolant Volumetric Flow Rate

Emergency Coolant Fluid Pressure

Emergency Coolant Fluid Temperature

Neutronic Power

Reflector Inlet Plenum Temperature

Reflector Material Temperature

Core Temperature

Pump Inlet Temperature

Nozzle Torus Temperature

Turbine Bypass Temperature

Control Drum Position

Pump Inlet Pressure

Pump Discharge Pressure
Number of

Channels

\section{5}

5

2

4

6

1

2

2

1

2

2

6

6

10

60

3

2

6

12

4

4 


\section{TABEE 2 (cont.)}

Parameter

TPA Gnoer

Pump Pressure Rise

Cooldown System Flow Rate

Cooldown Fluid Pressure

Cooldown Fluid Temperature

Gimbal Actuator Position

Neutron Flux (Facility Mounted Chambers)

Neutron Count Rate
Number of

Chamnels

4

2

1

2

2

2

3

6 
TABLE 3

FACILITY COMPUTER CALCULATION CRITERIA SUMMARY

Subroutine Name

Average - Reject

Average - Reject

Thrust

- Propellant Mass Flow Rate

.

Pressurization Fluid Mass Flow Rate

Specific Impulse

Signal Integrate

Derivative

Reactivity

Mass Flow Rate

NPSP

Feedback
Input Parameters

10 Chamber Pressures

10 Chamber Temperature

$\overline{\mathrm{P}} \mathrm{c}, \overline{\mathrm{T}} \mathrm{c}$

Propellant Volumetric

Flow Rate

Tank Pressure

Tank Temperature

Pressurization Fluid: Volumetric Flow Rate Pressure Temperature

F, M prop, M pres

Average Chamber Temperature

Average Chamber Pressure

Average Chamber

Temperature

Neutronic Power

Volumetric Flow Rate

Fluid Pressure

Fluid Temperature

Pump Inlet Pressure Pump Inlet Temperature

Reactivity Control Drum Position
Output Parameters

Average Chamber Pressure, $\overline{\mathrm{P}} \mathrm{c}$

Average Chamber Temperature, $\bar{T} c$

Thrust, F

Propellant Mass Flow

Rate, M prop

Pressurization Fluid

Mass Flow Rate, $M$ press

Specific Impulse

Total Time Above Tc $=4250^{\circ} \mathrm{R}$

$\frac{d P c}{d \theta}$

$\frac{d T c}{d \theta}$

Reactivity

Mass Flow Rate

NPSP at Pump Inlet

Hydrogen Feedback Reactivity 


\section{TABLE 3 (cont.)}

Page 2 of 2

Subroutine Name

Gimbal Angle

Gimbal Velocity

Gimbal Acceleration
Input Parameters

Gimbal Actuator

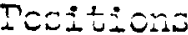

Gimbal Actuator Positions

Gimbal Actuator Positions
Output Parameters

Thrust Vector Angle

Gimballing Velocity

Gimballing Acceleration 


\section{$\operatorname{Iin} \operatorname{Iin} 4$}

EVENTS CHRONOLOGY

The facility computer will be programmed to record or otherwise retain the time of occurrence of each of the events listed below. The time of occurrence followed by a clear-text identifying statement of all such events during any selected time period will be listed or displayed sequentially upon demand.

\begin{tabular}{|c|c|c|c|}
\hline \multicolumn{3}{|c|}{ Summary of Chronology Statements } & \multirow{7}{*}{$\begin{array}{l}\text { On-off } \\
\text { Valves }\end{array}$} \\
\hline (Time) & (Valve Name)* & Commanded Open & \\
\hline$"$ & " & Starts to Open & \\
\hline$"$ & $"$ & Fully Oden & \\
\hline$"$ & $"$ & Commanded Closed & \\
\hline$"$ & $"$ & Starts to close & \\
\hline " & $"$ & Fully closed & \\
\hline$"$ & $"$ & Commanded Open & \\
\hline$"$ & $"$ & Starts Opening Transient & \\
\hline$"$ & $"$ & Stems Stationary at $\star * \%$ & Open \\
\hline$"$ & $n$ & Fully Open & Proportional \\
\hline$"$ & $"$ & Commanded Closed & Valves \\
\hline$"$ & $"$ & Start Closing Transient & \\
\hline$"$ & $"$ & Fully Closed & \\
\hline
\end{tabular}

*The list of engine and facility valves which may be selected by the events chronology subroutine is as follows: 
TABLE 4 (cont.)

Summary of Chronoloory Statements (Contimed)

(TIme)

"

n

n

11

$\boldsymbol{1}$

1

$\mathbf{T}$
TPA \#__ Rotation Starts

Reflector Inlet Pienum Temperature Reaches (TBD) ${ }^{\circ} \mathrm{R}$

Reactor Critical

Chamber Pressure Greater than (TBD) psia

Chamber Pressure Less than (TBD) psia

Chamber Temperature Greater than (TBD) ${ }^{\circ} \mathrm{R}$

Chamber Temperature Less than $(\text { TBD })^{\circ} \mathrm{R}$

Neutronic Power Greater than (IDBD) Megawatts

Neutronic-Power Less than (IBD) Megawatts 


\begin{tabular}{|c|c|c|c|}
\hline $\begin{array}{c}\mathrm{C}-002 \\
\text { Specification } \\
\text { Paragraph Number }\end{array}$ & Parameter & $\begin{array}{r}\text { Number of } \\
\text { Channels } \\
\end{array}$ & $\begin{array}{c}\text { Overal? } \\
\text { Channel Accuracy }\end{array}$ \\
\hline \multirow[t]{2}{*}{$3.1 .1 .1 .2(a)$} & Chamber Pressure & 5 & \\
\hline & Chamber Temperature & 5 & \\
\hline \multirow[t]{11}{*}{$3.1 .1 .1 .2(b)$} & Chamber Pressure & 10 & \\
\hline & Chamber Temperature & 10 & . \\
\hline & Propellant Volumetric Flow Rate & 2 & \\
\hline & Propellant Pressure & 4 & \\
\hline & Propellant Temperature & 6 & \\
\hline & $\begin{array}{l}\text { Pressurization Fluid Volumetric } \\
\text { Flow Rate }\end{array}$ & 1 & \\
\hline & Pressurization Fluid Pressure & 2 & \\
\hline & Pressurization Fluid Temperature & 2 & \\
\hline & Emergency Coolant Volumetric Flow Rate & 1 & \\
\hline & Emergency Coolant Fluid Pressure & 2 & \\
\hline & Emergency Coolant Fluid Temperature & 2 & \\
\hline $3.1 .1 .1 .2(\mathrm{c})$ & Chamber Pressure & 5 & \\
\hline $3.1 .1 .1 .2(d)$ & Chamber Temperature & 5 & \\
\hline
\end{tabular}


TABLR E-1 (cont.)

MEASUREMEMI SYSTEM CRITEERIA

\begin{tabular}{|c|c|c|c|c|}
\hline $\begin{array}{l}\text { C-002 } \\
\text { Specification } \\
\text { Paragraph Number }\end{array}$ & Parameter & 1 & $\begin{array}{r}\text { Number of } \\
\text { Channels }\end{array}$ & $\begin{array}{c}\text { Overall } \\
\text { Channel Accuracy }\end{array}$ \\
\hline $3.1 .1 .1 .2(\mathrm{e})$ & Chamber Temperature & & 5 & \\
\hline \multirow[t]{2}{*}{$3 \cdot 1 \cdot 1 \cdot 1 \cdot 3$} & Chamber Pressure & & 5 & \\
\hline & Chamber Temperature & & 5 & . \\
\hline 3.1 .1 .1 .5 .1 .1 & Neutronic Power & & 6 & \\
\hline \multirow[t]{12}{*}{$3.1 .1: 1.5 \cdot 1.2 .1$} & Propellant Volumetric Flow Rate & & 2 & \\
\hline & Propellant Pressure & & 6 & $\cdot$ \\
\hline & Propellant Temperature & & 6 & \\
\hline & Chamber Pressure & & 5 & $\cdot$ \\
\hline & Chamber Temperature & & 5 & $\therefore$ \\
\hline & Reflector Inlet Plenum Temperature & & 6 & \\
\hline & Reflector Material Temperature & 1 & 10 & \\
\hline & Core Temperature & & 60 & \\
\hline & Pump Inlet Temperature & & 3 & \\
\hline & Nozzle Torus Temperature & & 2 & \\
\hline & Turbine Bypass Temperature & & 6 & - \\
\hline & Neutronic Power & & 6 & \\
\hline 7 & Control Drum Position & & 12 & \\
\hline
\end{tabular}




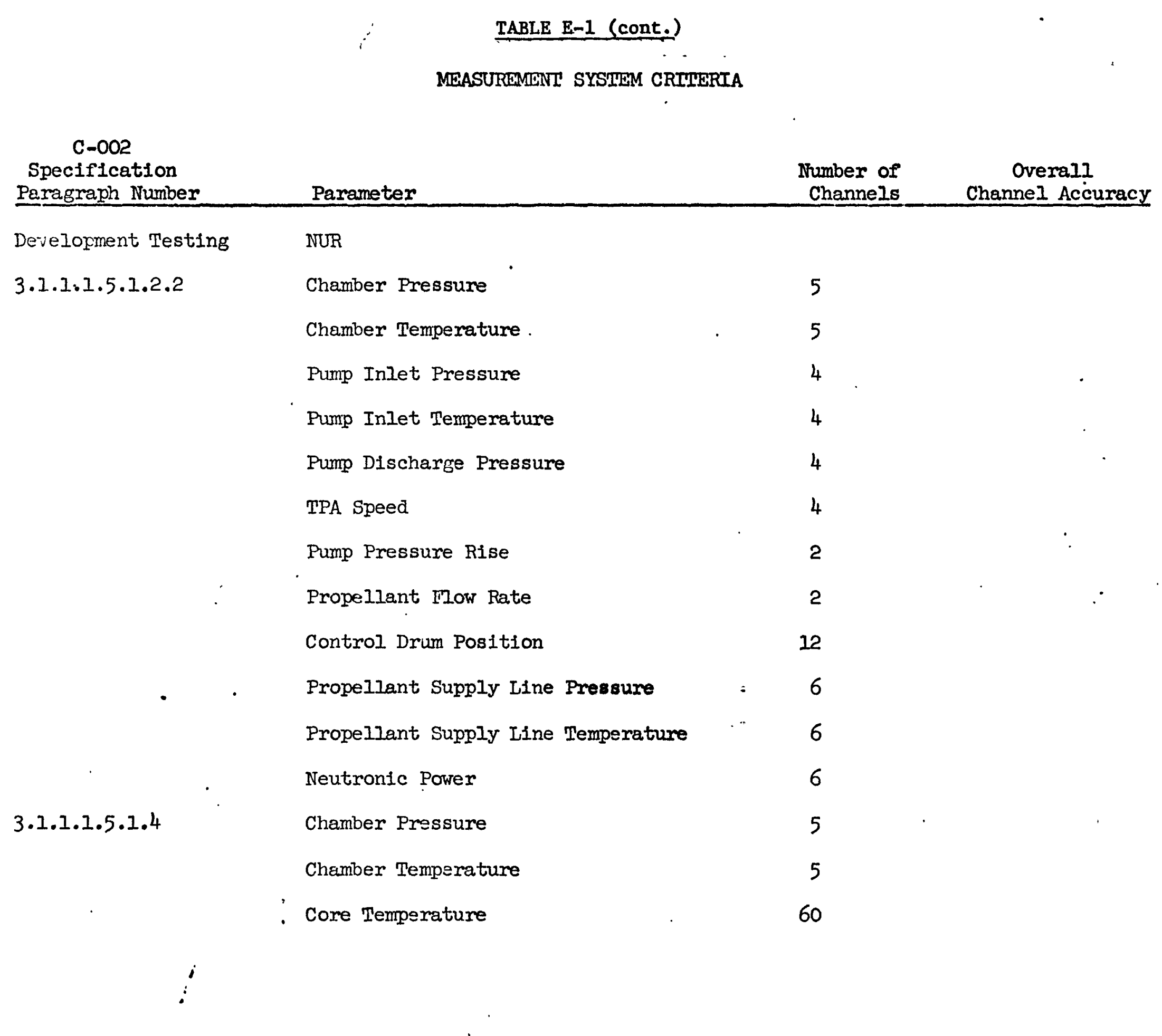


MEASUREMEI ! SYSTEM CRITERIA

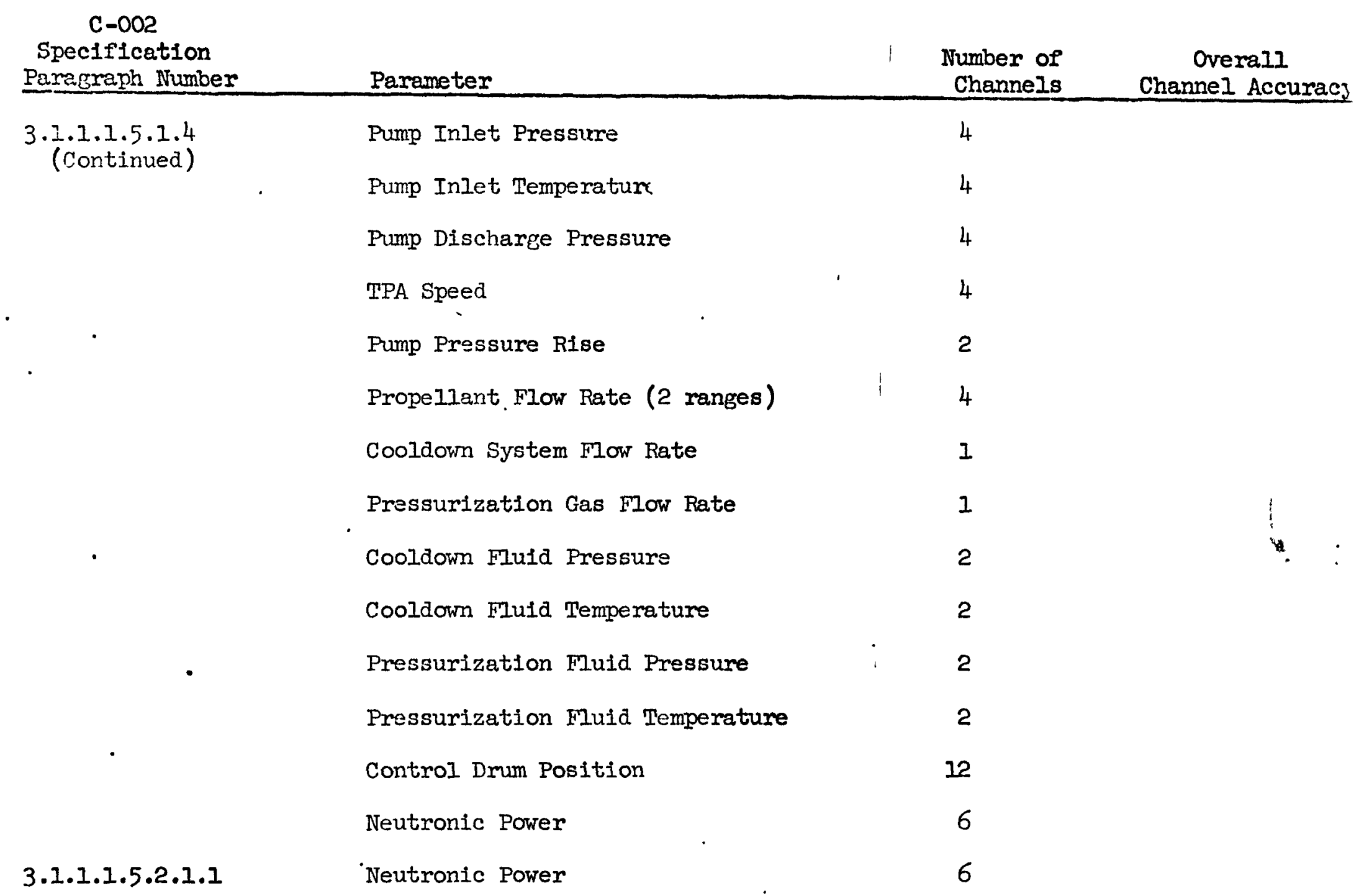


TABLE E-1 (cont.)

MEASUREMENT SYSTEM CRITERIA

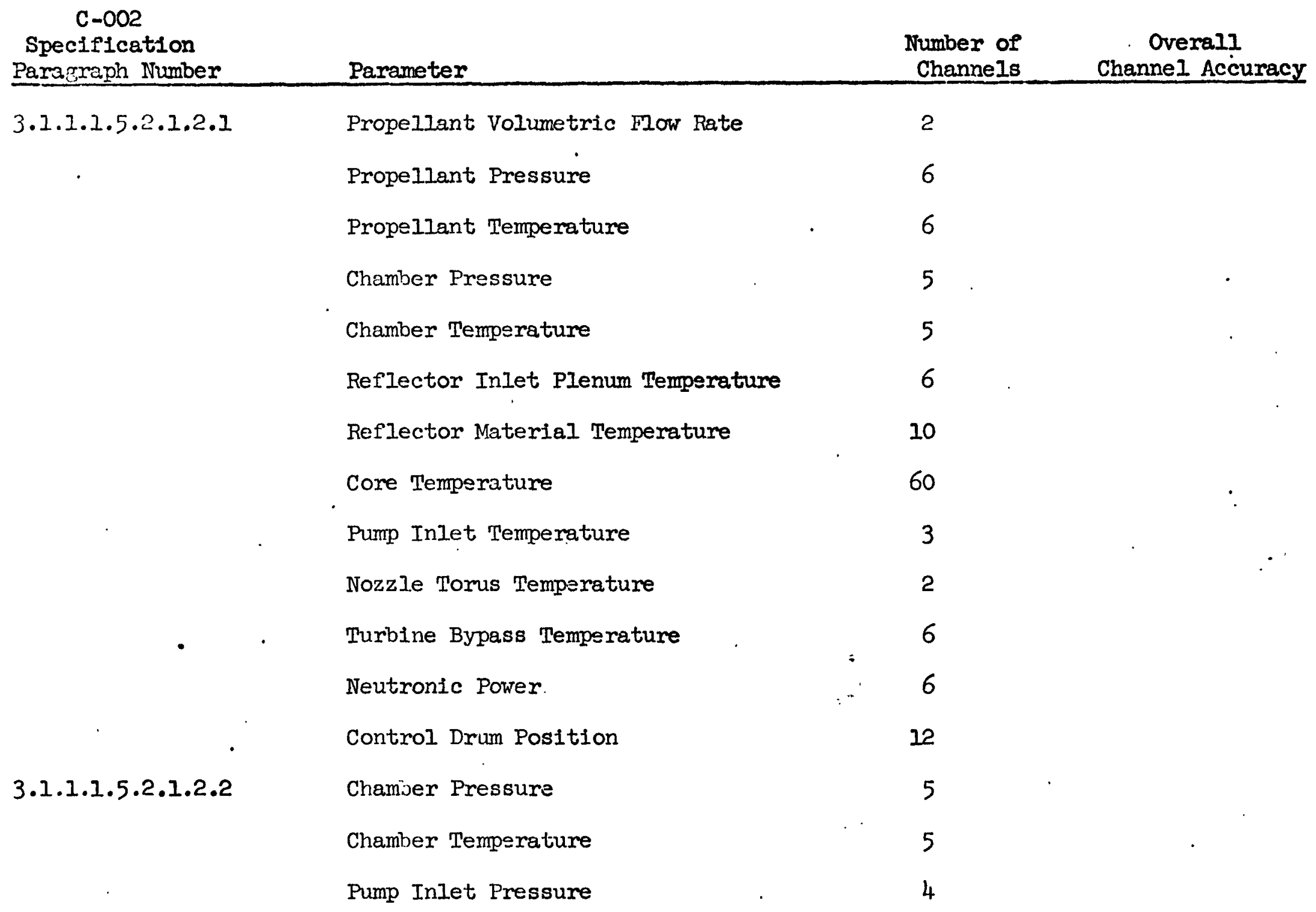


TABLE E-1 (cont.)

MEASUREMEIVI SYSTEM CRITHETA

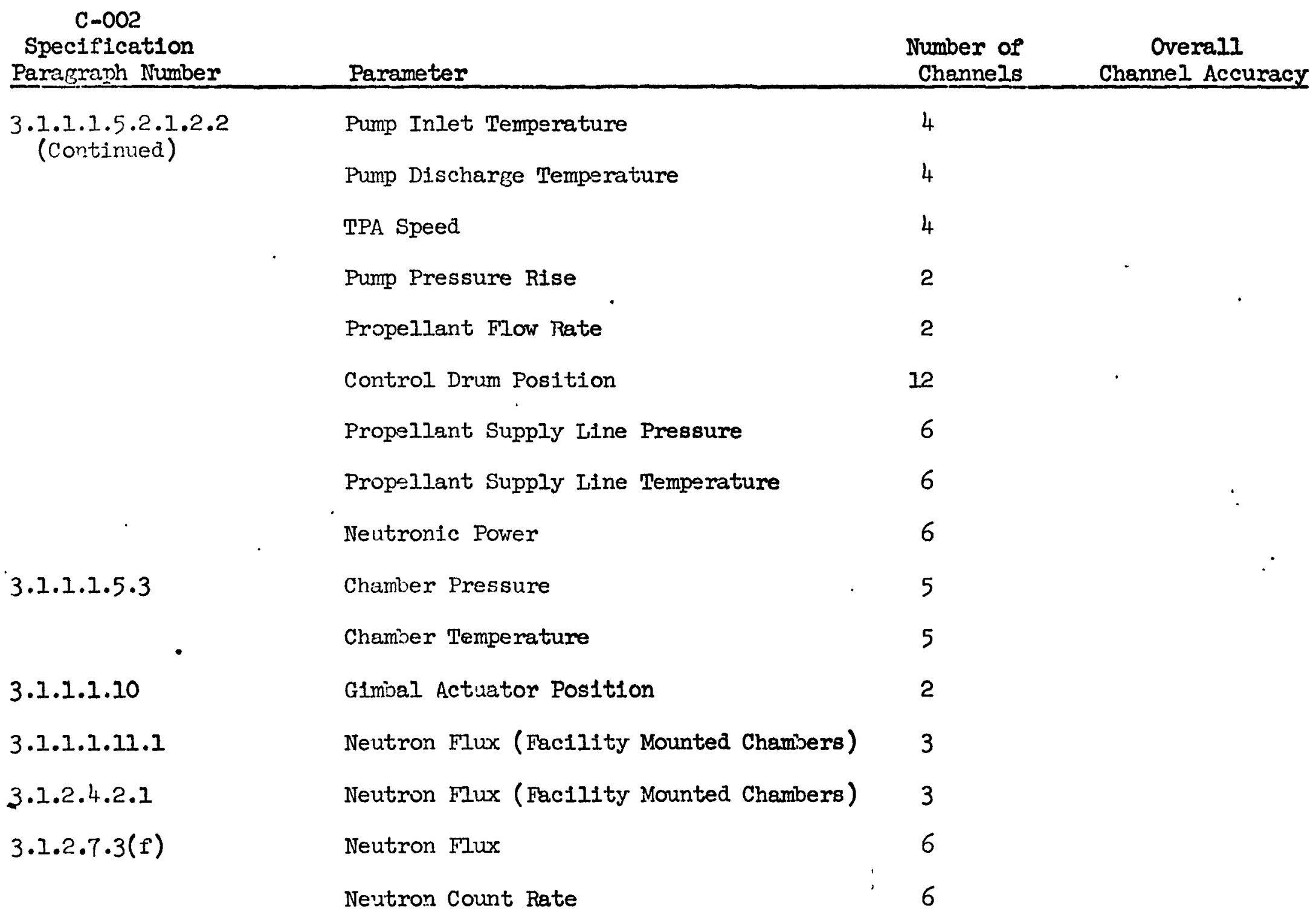




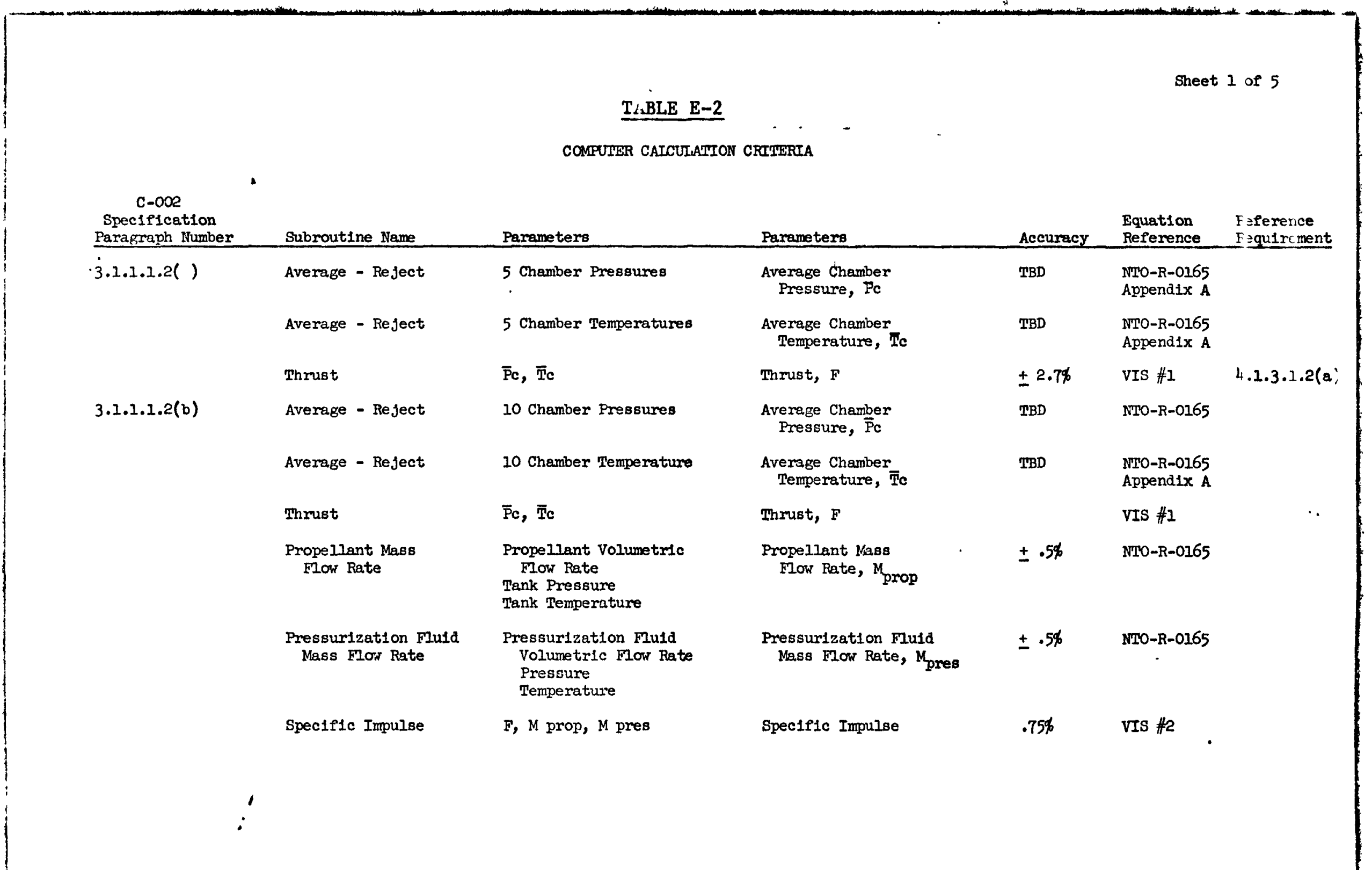


Sheet 2 of 5

TABLE E-2 (cont.)

COMPUIER CAICULATION CRITERTA

\begin{tabular}{|c|c|c|c|c|c|}
\hline $\begin{array}{l}\text { C-OCe } \\
\text { Specification } \\
\text { Paragraph Number }\end{array}$ & Subroutine Name & $\begin{array}{c}\text { Input } \\
\text { Parameters }\end{array}$ & $\begin{array}{c}\text { Output } \\
\text { Parameters } \\
\end{array}$ & Accuracy & $\begin{array}{l}\text { Equation } \\
\text { Reference }\end{array}$ \\
\hline $3.1 .1 .1 .2(c)$ & Average - Reject & 5 Chamber Pressure & Average Chamber Pressure & & $\begin{array}{l}\text { Nro-R-0165 } \\
\text { Append1x A }\end{array}$ \\
\hline $3.1 .1 .1 .2(d)$ & Average - Re Ject & 5 Chamber Temperature & Average Chamber Temperature & & $\begin{array}{l}\text { NTO-R-0103 } \\
\text { Append1x A }\end{array}$ \\
\hline $3.1 .1 .1 .2(e)$ & Signal Integrate & $\begin{array}{l}\text { Average Chamber } \\
\text { Temperature }\end{array}$ & $\begin{array}{c}\text { Total time above } \\
\text { Tc }=4250^{\circ} \mathrm{R}\end{array}$ & $\pm .2 \mathrm{sec}$ & $\mathrm{NIO}-\mathrm{R}-0165$ \\
\hline \multirow[t]{2}{*}{3.1 .1 .1 .3} & Derivative & $\begin{array}{l}\text { Average Chamber } \\
\text { Pressure }\end{array}$ & $\frac{\mathrm{d} P c}{\mathrm{~d} \theta}$ & $\pm .5 \frac{\mathrm{ps} 1}{\mathrm{sec}}$ & $\begin{array}{l}\text { MIRACLE } \\
\text { Volume I, Afpend1x B }\end{array}$ \\
\hline & & $\begin{array}{l}\text { Average Chamber } \\
\text { Temperature }\end{array}$ & $\frac{\mathrm{d} T \mathrm{c}}{\mathrm{d} \theta}$ & $\pm \frac{10^{\circ}}{\sec }$ & \\
\hline 3.1 .1 .1 .5 .1 .1 & Reactivity & Neutronic Power & Reactivity & THB & $\begin{array}{l}\text { MIRACLE } \\
\text { Volume I, AI pendix A }\end{array}$ \\
\hline \multirow[t]{2}{*}{3.1 .1 .1 .5 .1 .2} & Mass Flow Rate & $\begin{array}{l}\text { Volumetric Flow Rate } \\
\text { Fluid Pressure } \\
\text { Fluid Temperature }\end{array}$ & Mass Flow Rate & TMBD & NTO-R-0165 \\
\hline & Signal Integrate & Mass Flow Rate & Total Flow & TBD & NTO-R-0165 \\
\hline
\end{tabular}




\section{TABLF: E-2 (cont.)}

Sheet 3 of :

COMPUIER CAICULATTON CRITIRTIA

\begin{tabular}{|c|c|c|c|c|c|}
\hline $\begin{array}{c}\text { C-00e } \\
\text { Spectelcation } \\
\text { Paragraph Number }\end{array}$ & Subroutine Name & $\begin{array}{c}\text { Input } \\
\text { Parameters }\end{array}$ & $\begin{array}{c}\text { Output } \\
\text { Parameters }\end{array}$ & Accuracy & $\begin{array}{l}\text { Equation } \\
\text { Reference }\end{array}$ \\
\hline \multirow[t]{3}{*}{$3.1 .1 .1 .5 \cdot 1.2 .2$} & NPSP & $\begin{array}{l}\text { Pump Inlet Pressure } \\
\text { Pump Inlet Temperature }\end{array}$ & NPSP of Pump Inlet & & NTO-R-0165 \\
\hline & NPSP & $\begin{array}{l}\text { Tank Pressure } \\
\text { Tank Temperature }\end{array}$ & NPSP at PSOV & & NMO-R-0165 \\
\hline & Mass Flow Rate & $\begin{array}{l}\text { Propellant Volumetric } \\
\text { Flow Rate } \\
\text { Propellant Pressure } \\
\text { Propellant Temperature }\end{array}$ & Propellant Mass Flow Rate & & NPO-R-0165 \\
\hline \multirow{7}{*}{. } & Average - Reject & Chamber Pressure & $\overline{\mathrm{P}} \mathbf{c}_{\mathbf{c}}$ & & NTO-R-0165 \\
\hline & Average - Reject & Chamber Temperature & $\overline{\mathbf{T}} \mathbf{c}$ & & NTO-R-0165 \\
\hline & Thrust & $\overline{\mathrm{P}} \mathrm{c}, \overline{\mathrm{T}} \mathrm{c}$ & Thrust, $F$ & & $\begin{array}{l}\text { VIS \#1 } \\
\text { NASA TN-D-132 }\end{array}$ \\
\hline & Specific Impulse & $\overline{\mathrm{P}} \mathrm{c}, \overline{\mathrm{T}} \mathrm{c}$ & Isp & & $\begin{array}{l}\text { VIS \#2 } \\
\text { NASA TN-D-132 }\end{array}$ \\
\hline & Signal Integrate & $\mathbf{F}$ & Total Impulse & & TBD \\
\hline & Reactivity & Neutronic Power & Reactivity & & $\begin{array}{l}\text { MIRACLE } \\
\text { Volume I, Appendix A }\end{array}$ \\
\hline & Feedback & $\begin{array}{l}\text { Reactivity } \\
\text { Control Drum Position }\end{array}$ & Hydrogen Feedback Reactivity & & TBD \\
\hline
\end{tabular}




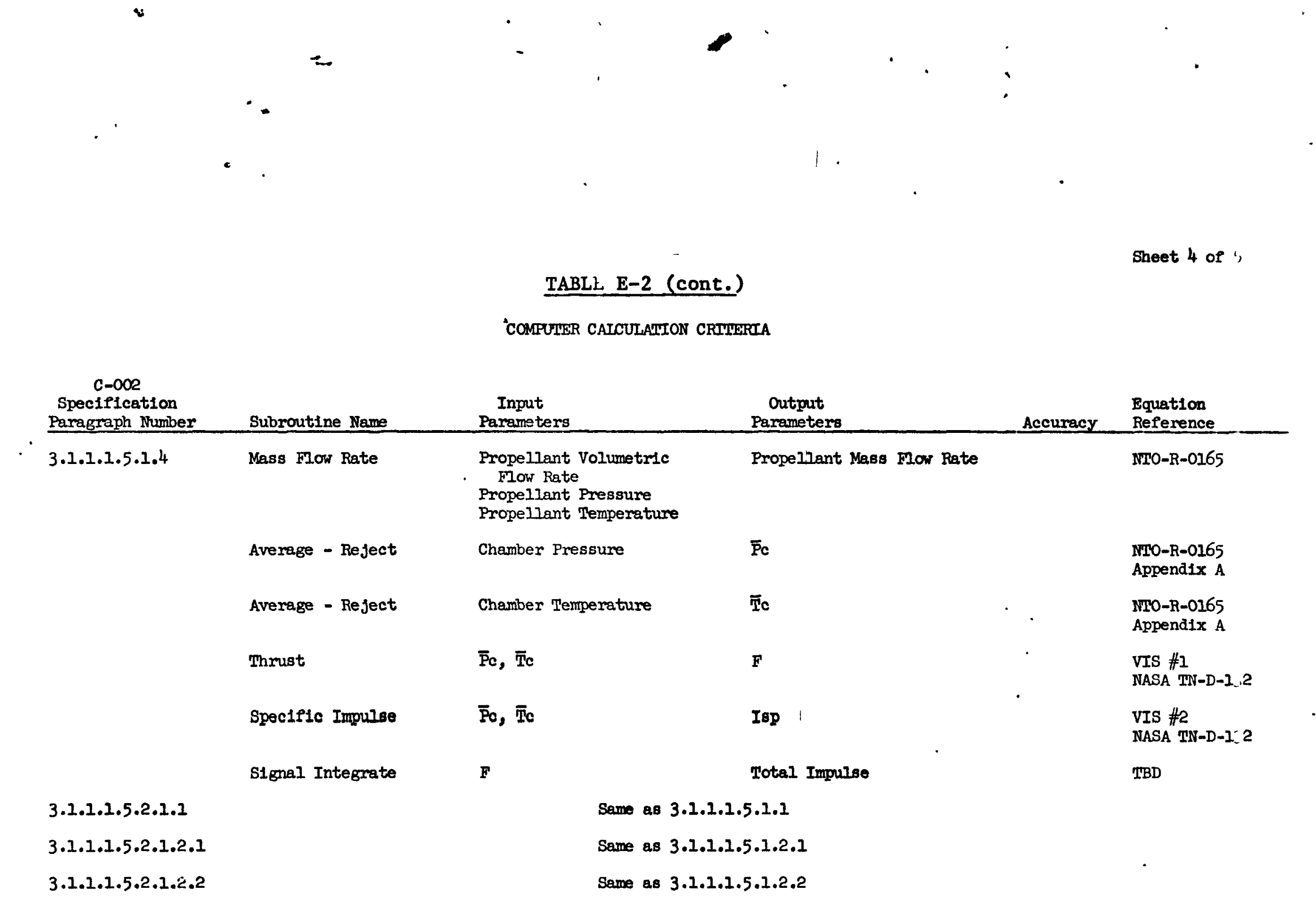




\section{TABLE E-2 (cont.)}

Sheet 5 of 5

\section{COMPUTER CAICULAIIION CRITHETIA}

\begin{tabular}{|c|c|c|c|c|c|}
\hline $\begin{array}{c}\text { C-O0R } \\
\text { Specification } \\
\text { Paragraph Number }\end{array}$ & Subroutine Name & $\begin{array}{c}\text { Input } \\
\text { Parameters }\end{array}$ & $\begin{array}{c}\text { Output } \\
\text { Parameters }\end{array}$ & Accuracy & $\begin{array}{l}\text { Rquation } \\
\text { Reference }\end{array}$ \\
\hline \multirow[t]{3}{*}{$3.1 .1 .1 \cdot 5 \cdot 3$} & Average - Reject & 5 Chamber Pressure & $\overline{\mathrm{Pe}}$ & & $\begin{array}{l}\text { NTO-R-0165 } \\
\text { Appendix A }\end{array}$ \\
\hline & Average - Re Ject & 5 Chamber Temperature & $\overline{\mathrm{T}} \mathbf{c}$ & & $\begin{array}{l}\text { NTO-R-0165 } \\
\text { Appendix A }\end{array}$ \\
\hline & Thrust & $\overline{\mathrm{P}} \mathrm{c}, \overline{\mathrm{T}} \mathrm{c}$ & Thrust, $F$ & & VIS \#I \\
\hline \multirow[t]{2}{*}{$\cdot$} & S1gnal Integrate & $F$ & Total Impulse & & TBD \\
\hline & Spectfic Impulse & $\overline{\mathrm{P}} \mathrm{c}, \overline{\mathrm{T}} \mathrm{c}$ & Spec1fic Impulse & & NASA TN-D-275 \\
\hline \multirow[t]{3}{*}{3.1 .1 .1 .10} & Gimbal Angle & Gimbal Actuator Positions & Thrust Vector Angle & & THBD \\
\hline & Gimbal Velocity & Gimbal Actuator Positions & Gimballing Velocity & & TBD \\
\hline & Bimgal Acceleration & Gimbel Actuator Position. & Olmballing Acceleration & & TBD \\
\hline \multirow[t]{2}{*}{$3.1 .2 \cdot 7 \cdot 3(\mathrm{r})$} & Reactivity & Neutron Flux & ReactIvity & & $\begin{array}{l}\text { MIRACIR } \\
\text { Volume I, Appendix }\end{array}$ \\
\hline & Reactivity & Neutron Count Rate & Reactivity & & \\
\hline
\end{tabular}


TABLE F-1

PROPELIANT

FLUID FEQTIREMTINIS AT INIERFACE

\begin{tabular}{|c|c|c|c|c|c|c|c|c|}
\hline \multirow{2}{*}{$\begin{array}{c}\text { C-002 } \\
\text { Specification } \\
\text { Paragraph Number }\end{array}$} & \multicolumn{2}{|c|}{ Mass Flow Rate } & \multicolumn{2}{|c|}{ Pressure } & \multicolumn{2}{|c|}{ Temperature } & \multirow[b]{2}{*}{ Duration } & \multirow{2}{*}{$\begin{array}{l}\text { Total Fluid } \\
\text { Utilization }\end{array}$} \\
\hline & Maximum & Minimum & Maximum & Minimum & Maximum & Minimum & & \\
\hline & $\operatorname{Ibs}(\mathrm{m})$ & $7 \mathrm{sec}$ & & & & $\bar{K}$ & & $\overline{l b}:(\mathrm{rr})$ \\
\hline $3.1 .1 .1 .2(a)$ & $47.4 *$ & $44.8 *$ & 30.0 & 24.0 & 41.1 & 39.1 & $30 \mathrm{~min}$ & 170,540 \\
\hline $3.1 .1 .1 .2(1)$. & $47.4 *$ & $44.8 *$ & 30.0 & 24.0 & 41.1 & 39.1 & $30 \mathrm{~min}$ & 170.540 \\
\hline $3.1 .1 .1 .2(c)$ & $47.4 *$ & $44.8 *$ & 30.0 & 24.0 & 41.1 & 39.1 & $30 \mathrm{~min}$ & 170.640 \\
\hline $3.1 .1 .1 .2(d)$ & $47.4 *$ & $44.8 *$ & 30.0 & 24.0 & 41.1 & 39.1 & $30 \min$ & 170,640 \\
\hline $3.1 .1 .1 .2(e)$ & $47.4 *$ & $26.4 *$ & 30.0 & 24.0 & 41.1 & 39.1 & $60 \mathrm{~min}$ & 341,680 \\
\hline $3.1 .1 .1 .3 \quad r$ & $47.4 *$ & 0 & 30.0 & 12.8 & 41.0 & 39.1 & Indeterminate ${ }^{* *}$. & Ind $\epsilon$ terminat $e^{* *}$ \\
\hline $3.1 .1 .1 .1+2$ & $47.4 *$ & 0 & 30.0 & 12.8 & 41.0 & 39.1 & Indeterminate** & Inde terninat $2^{* *}$ \\
\hline 3.1 .1 .1 .5 .1 .1$)$ & .15 & 0 & 30.0 & 12.8 & 41.0 & 39.1 & TBD & TED \\
\hline 3.1 .1 .1 .5 .1 .2 .1 & TBD & & 30.0 & 12.8 & 41.0 & 39.1 & TBD & TBD \\
\hline Development Testing & TBD & & & & & & & \\
\hline 3.1 .1 .1 .5 .1 .2 .2 & $47 \cdot 4 *$ & 0 & 30.0 & 12.8 & 41.0 & 39.1 & $36 \mathrm{sec}$ & TBD \\
\hline 3.1 .1 .1 .5 .1 .4 & $29.0 *$ & 0 & 30.0 & 12.8 & 41.1 & 39.1 & TBD & TBD \\
\hline
\end{tabular}

* Values given represent requirements for each of the two Propellant Supply Iine (PSL) interfaces.

* Hapine runs of varying flow rate, power level and duration will be planned. 



\section{TABLE F-2}

PRESSURI7ATION

FLUID REQUIREMENTS AT INTERFACE

$\mathrm{C}-002$

Specification

Paragraph Number

\begin{tabular}{|c|c|c|c|c|c|c|c|c|c|}
\hline $3.1 .1 .1 .2(a)$ & .51 & .43 & 729 & 674 & 295 & & 243 & $30 \mathrm{~min}$ & 918 \\
\hline $3.1 .1 .1 .2(b)$ & .51 & .43 & 729 & 674 & 295 & & 243 & $30 \min$ & 913 \\
\hline $3.1 .1 .1 .2(\mathrm{c})$ & .51 & .43 & 729 & 674 & 295 & & 243 & $30 \min$ & 918 \\
\hline $3.1 .1 .1 .2(d)$ & .51 & .43 & 729 & 674 & 295 & & 243 & $30 \min$ & 918 \\
\hline $3.1 .1 .1 .2(\mathrm{e})$ & .51 & .25 & 729 & 425 & 336 & & $2+3$ & $60 \mathrm{~min}$ & 1835 \\
\hline $3 \cdot 1 \cdot 1 \cdot 1 \cdot 3$ & .51 & 0 & 729 & 12.8 & 336 & & 243 & Indeterminate** & Inde terminat $* * *$ \\
\hline 3.1 .1 .1 .4 & .51 & 0 & 729 & 12.8 & 336 & & 243 & Indeterminate ${ }^{* *}$ & $\therefore$ Inde terminat,$* *$ \\
\hline $3.1 .1 .1 .5 \cdot 1.2 .2$ & $.5 I$ & 0 & 729 & 12.8 & 336 & & 243 & $36 \mathrm{sec}$ & $>20$ \\
\hline $3 \cdot 1.1 .1 \cdot 5 \cdot 1.4$ &. .33 & 0 & 459 & 12.8 & 335 & $\because$ & 284 & & \\
\hline 3.1 .1 .1 .5 .2 .1 .2 .2 & .42 & .34 & 589 & 556 & 299 & $*^{3}$ & 249 & & \\
\hline $3 \cdot 1.1 \cdot 1 \cdot 5 \cdot 2 \cdot 1 \cdot 3$ & .42 & .34 & 589 & 556 & 299 & & 249 & $30 \mathrm{~min}$ & 756 \\
\hline
\end{tabular}

Toti 1 Fruid

Utilization Meximum Minimu

Pressure

Temperature

Duration

Iization

psia

Maximum Minimam

Duration


COOLDOWN

FLUID REQUIREMENTS AT INIEERFACE

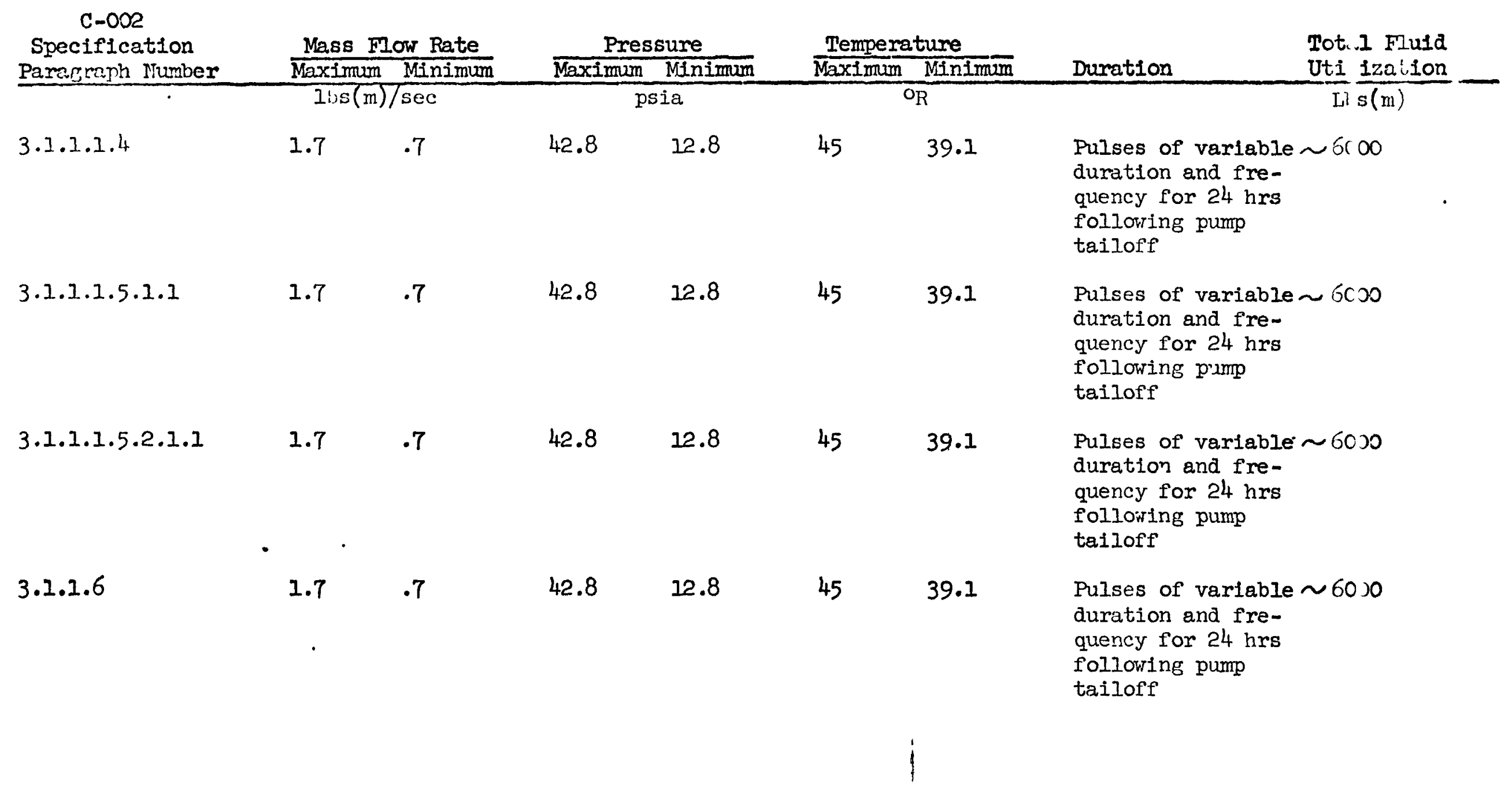




\section{TABLE F-4}

\section{EMER'AEN YY COOLDOWN}

FLUID REQUIRE IENIS AT INIERFACE

\section{C-002}

Specification

Paracrani Number

Mass Flow Rate

Maximum Minimum

Pressure

Maximum Min'mum

Temperature

Total Fluid $\operatorname{Lbs}(\mathrm{m}) / \mathrm{sec}$

Maximum Minimum

Utilization

$3.1 .1 .1 .2(b)$

1.0

1447

1328

63.4

59.6

$30 \mathrm{~min}$

1800 